\title{
Efek Pemberian Protein Rekombinan Fusi ESAT6-CFP10 Mycobacterium tuberculosis terhadap Persentase IL2 dan IL10 yang Dipresentasikan Sel T CD8 pada Kultur PBMC
}

\section{Effect of Mycobacterium tuberculosis's ESAT6-CFP10 Recombinant Fusion Protein Addition on IL2 and IL10 Percentages which Presented by CD8 T Cell in PBMC Culture}

\author{
David Christianto ${ }^{1}$, Tri Yudani $M R^{2}$, Sumarno ${ }^{3}$, Maimun Zulhaidah $A^{4}$, Triwahju Astuti, Teguh Wahyu $S^{6}$, \\ Noorhamdani $A S^{7}$ \\ ${ }^{1}$ Program Studi Ilmu Biomedik Fakultas Kedokteran Universitas Brawijaya Malang \\ ${ }^{2}$ Departemen Biokimia Biomolekuler Fakultas Kedokteran Universitas Brawijaya Malang \\ ${ }^{3,7}$ Departemen Mikrobiologi Klinik Fakultas Kedokteran Universitas Brawijaya Malang \\ ${ }^{4}$ Departemen Patologi Klinik Fakultas Kedokteran Universitas Brawijaya Malang \\ ${ }^{5}$ Departemen Pulmonologi dan Kedokteran Respirasi Fakultas Kedokteran Universitas Brawijaya Malang \\ ${ }^{6}$ Departemen Parasitologi Fakultas Kedokteran Universitas Brawijaya Malang
}

\begin{abstract}
ABSTRAK
Keberhasilan vaksin BCG dalam memberikan perlindungan terhadap tuberkulosis (TB) pada orang dewasa di Indonesia belum optimal (37\%) sehingga diperlukan vaksin alternatif yang lebih efektif. Protein rekombinan fusi ESAT6-CFP10 merupakan kandidat vaksin yang potensial. Penelitian dilakukan untuk menguji efektifitas protein rekombinan fusi ESAT6CFP10 dalam meningkatkan ekspresi IL2 dan IL10 sel T CD8 yang memainkan peran penting dalam respon imun melawan TB. Pengujian kandidat vaksin dilakukan secara in vitro pada peripheral blood mononuclear cell (PBMC) dari kelompok sehat endemik TB, kelompok kontak TB, dan kelompok pasien TB dengan melihat persentase IL2 dan IL10 CD8. Setiap kelompok diberi perlakuan tanpa antigen, PPD, dan protein rekombinan fusi ESAT6-CFP10. Persentase IL2 meningkat secara signifikan dari kelompok sehat, kontak TB, hingga Pasien TB. Sebaliknya peningkatan persentase IL2 antar kelompok yang dipaparkan PPD tidak signifikan secara statistik $(p=0,396)$. Persentase IL10 tidak menunjukkan perbedaan yang signifikan antar kelompoknya baik tanpa paparan antigen $(p=0,617)$, PPD $(p=0,351)$, maupun protein rekombinan fusi ESAT6-CFP10 $(p=0,257)$. Didapatkan persentase IL2 yang tidak berbeda secara signifikan antar perlakuan pada kelompok sehat $(p=0,309)$, kelompok kontak TB $(p=0,318)$, dan kelompok pasien TB $(p=0,424)$. Demikian juga dengan persentase IL10 yang tidak berbeda secara signifikan antar perlakuan pada kelompok sehat $(p=0,908)$, kelompok kontak TB ( $p=0,352)$, dan kelompok pasien TB $(p=0,776)$. Hal ini menunjukkan bahwa protein fusi rekombinan ESAT6-CFP10 dapat meningkatkan persentase IL2 tetapi tidak dengan IL10 meskipun secara statistik tidak signifikan.
\end{abstract}

Kata Kunci: CD8, IL2, IL10, Mycobacterium tuberculosis, protein rekombinan fusi ESAT6-CFP10

\begin{abstract}
The success of BCG vaccine in protecting against tuberculosis (TB) in adults in Indonesia is not optimal (37\%), thus more effective alternative vaccines are needed. ESAT6-CFP10 recombinant fusion protein is a potential vaccine candidate. This study was conducted to test the effectiveness of ESAT6-CFP10 fusion recombinant protein in increasing the expressions of IL2 and IL10 CD8 T cells which play an important role in the immune response against TB. The candidate vaccine testing was carried out in vitro on peripheral blood mononuclear cell (PBMC) from healthy TB endemic group, TB contact group, and TB patients group by looking at the percentage of IL2 and IL10 CD8. Each group was treated without antigen, PPD, and ESAT6CFP10 fusion recombinant protein. The percentage of IL2 increased significantly from healthy group, TB contact, and TB patients. On the contrary, an increase in the percentage of IL2 between groups exposed to PPD was not statistically significant ( $p=0.396)$. The percentage of IL10 did not show a significant difference between groups either without antigen exposure ( $p=0.617)$, PPD $(p=0.351)$, or ESAT6-CFP10 recombinant fusion protein $(p=0.257)$. The percentage of IL2 was not significantly different among treatments in the healthy group $(p=0.309)$, TB contact group $(p=0.318)$, and TB patient group $(p=0.424)$. Likewise, the percentage of IL10 did not differ significantly between treatments in the healthy group $(p=0.908)$, TB contact group $(p=0.352)$, and the TB patient group $(p=0.776)$. This shows that the ESAT6-CFP10 recombinant fusion protein can increase the percentage of IL2 but not IL10 although statistically not significant.
\end{abstract}

Keywords: CD8, ESAT6-CFP10 recombinant fusion protein, IL2, IL10, Mycobacterium tuberculosis

Korespondensi: David Christianto. Program Studi Ilmu Biomedik Fakultas Kedokteran Universitas Brawijaya Malang, Jl. Veteran Malang 65145 Tel.089661322333Email:dvidchristianto@gmail.com 


\section{PENDAHULUAN}

Tuberkulosis (TB) merupakan penyakit infeksi yang disebabkan oleh bakteri Mycobacterium tuberculosis (Mtb). Tuberkulosis biasa menyerang paru, akan tetapi juga dapat terjadi pada bagian tubuh yang lain. Kejadian TB di dunia hingga saat ini terdapat 10,4 juta kasus baru dan diperkirakan terdapat 1,4 juta kasus meninggal pada tahun 2015 yang disebabkan oleh T (1). Upaya untuk mencegah kasus baru TB dan terjadinya kematian oleh karena TB sudah dilakukan di seluruh dunia dengan vaksinasi dan pemberian obat-obatan untuk pasien TB (2).

Vaksin yang tersedia untuk TB hanyalah Bacillus Calmette Guerin (BCG) yang berasal dari Mycobacterium bovis (M.bovis) galur Paris yang hidup dan dilemahkan. Efektivitas perlindungan terhadap TB paru dari vaksin BCG memiliki variabilitas dengan rentang dari 0-85\%, sedangkan di Indonesia sebesar $37 \%$ (3). Hal ini menyebabkan sekalipun vaksin BCG sudah digunakan sejak 80 tahun terakhir, orang yang mendapat vaksinasi BCG masih dapat terkena TB paru. Pada anak yang diberi vaksin BCG akan terlindungi dari TB milier dan meningitis $\mathrm{TB}$, namun seiring dengan bertambahnya usia akan kehilangan perlindungan terhadap TB (4). Hal ini mengakibatkan manifestasi TB kerap terjadi pada usia dewasa meskipun telah divaksinasi BCG (1). Selain itu BCG juga dapat menjadi penyakit aktif apabila diberikan pada orang dengan kelemahan kekebalan tubuh. Jika dibandingkan dengan Mtb, maka BCG juga dapat dikatakan memiliki komponen yang cukup berbeda, yaitu pada BCG tidak didapatkan Regio of Difference yang bertugas mensekresikan faktor virulensi dari Mtb. Dengan beberapa kelemahan diatas maka diperlukan kandidat vaksin baru yang dapat memberikan perlindungan yang lebih efektif terutama di negara-negara berkembang dengan prevalensi TB yang tinggi.

Salah satu kandidat vaksin baru yang diharapkan dapat memberikan respon imun yang lebih efektif berasal dari antigen filtrat kultur Mtb (5). Antigen Mtb, Early Secreted Antigenic Target (ESAT6) dan Culture Filtrate Protein (CFP10) disekresikan pada awal infeksi, kedua antigen ini mengenali epitop imunodominan dari sel T (6). ESAT6 merupakan protein Mtb yang diketahui memiliki efek inhibisi autofagi, menginduksi apoptosis makrofag melalui aktivasi ekspresi kaspase, dan melisiskan membran fagosom, sehingga kerusakan pada ESAT6 berhubungan dengan perbaikan fusi autofago-lisosom dari sel dendrit terhadap Mtb. Sedangkan CFP10 bekerja dengan menurunkan produksi Nitric Oxide (NO) dan Reactive Oxygen Species (ROS) yang dihasilkan oleh makrofag, sehingga menghambat kemampuan membunuh makrofag $(4,7)$. Pada vaksin BCG yang ditambahkan Regio of Difference-1 (RD1) yang mengkode ESAT6 dan CFP10 didapatkan peningkatan imunogenitas dari vaksin tersebut (8).

Peningkatan imunogenitas pada kandidat vaksin salah satunya dapat diukur dengan melihat kemampuan kandidat vaksin dalam menginduksi respon imun seluler berupa peningkatan produksi interlekuin-2 (IL2) dan interleukin-10 (IL10) dari sel T CD8. Interleukin-2 merupakan sitokin pertumbuhan yang bertanggung jawab atas proliferasi dan diferensiasi dari sel CD4 dan CD8 serta meningkatkan produksi immunoglobulin dari sel plasma (9). Selain itu IL2 juga berperan sebagai faktor pertumbuhan dan diferensiasi dari sel NK, sel limfosit B, dan sel limphokine-activated killer (LAK) (10). Keberadaan
IL2 diketahui ikut meningkatkan kadar Interferon Gamma (IFN- $\gamma$ ) yang diproduksi oleh sel T CD8 (11). IL10 merupakan sitokin anti-inflamasi poten dengan peran penting dalam membatasi respon pro-inflamasi dan mencegah penyakit autoimun (9). Selain itu IL10 yang diproduksi mampu meningkatkan aktivitas sitotoksik dari sel NK dan sel CD8 serta merangsang terbentuknya sel T memori CD8 untuk menghadapi infeksi berikutnya (12).

Konsorsium TB Indonesia sedang mengembangkan kandidat vaksin protein rekombinan ESAT6-CFP10 yang berasal dari galur lokal. Pnelitian ini bertujuan menguji efektivitas protein rekombinan fusi ESAT6-CFP10 Mtb dalam meningkatkan ekspresi sitokin IL2 dan IL10 dari sel T CD8. Pengujian kandidat vaksin dilakukan secara in vitro pada peripheral blood mononuclear cell (PBMC) dari kelompok sehat endemik TB, kelompok kontak TB, dan kelompok pasien TB dengan melihat persentase IL2 dan IL10 CD8.

\section{METODE}

Pemilihan subjek penelitian dilakukan dengan menggunakan metode consecutive sampling, yaitu setiap subjek yang memenuhi kriteria akan dijadikan subjek penelitian. Subjek yang telah bersedia mengikuti penelitian kemudian menjalani serangkaian prosedur pemeriksaan untuk menyingkirkan kemungkinan adanya infeksi atau faktor lain yang dapat menyebabkan bias pada penelitian. Kriteria inklusi untuk subjek kontrol endemik (sehat) adalah dokter dan paramedis sehat yang tidak pernah kontak dengan pasien TB selama lebih dari 6 bulan sebelumnya dengan gambaran foto dada tidak terdapat gambaran lesi tuberkulosis, sputum sewaktu-pagisewaktu (SPS) negatif, dan mantoux tes negatif. Kriteria inklusi untuk subjek kontak TB positif adalah dokter/paramedis dan keluarga pasien TB yang telah melakukan kontak langsung dengan pasien TB atau sampel biologis atau kultur dari pasien TB selama lebih dari 6 bulan dan tidak mempunyai riwayat TB sebelumnya. Pada gambaran foto toraks dan sputum SPS tidak menunjukkan tuberkulosis dengan mantoux tes positif. Kriteria inklusi untuk pasien tuberkulosis didiagnosis berdasarkan klinis dan radiologis. Terdapat riwayat batuk, febris, kakesia, dan gambaran foto toraks menunjukkan lesi tuberkulosis. Penyakit aktif dikonfirmasi dengan ditemukan lebih dari 2 bakteri per 10 lapang pandang pada pengecatan Ziehl-Neelsen atau ditemukan bakteri Mtb pada kultur dahak. Pasien baru didiagnosis atau baru mendapatkan terapi kurang dari 1 bulan.

Kriteria ekslusi untuk subjek penelitian antara lain tidak terinfeksi Human Immunodeficiency Virus (HIV), Hepatitis $B$, dan hepatitis $C$, hasil pemeriksaan normal untuk pemeriksaan laboratorium darah lengkap, fungsi hati, dan fungsi ginjal, untuk wanita tidak sedang hamil atau merencanakan kehamilan, serta rentang usia subjek penelitian antara 18-50 tahun. Pada awalnya subjek penelitian diambil darahnya sebanyak $3 \mathrm{~mL}$ untuk pemeriksaan darah lengkap, $5 \mathrm{~mL}$ untuk fungsi hati dan ginjal, serta serologis HIV. Setelah itu dilakukan pemeriksaan urin untuk melihat sedimen urin, foto $\mathrm{X}$-ray thorax PA untuk menilai lesi TB, tes mantoux dengan PPD RT 23-25 TU untuk menilai antibodi terhadap TB, dan pemeriksaan sputum SPS sebagai penentu diagnosa TB. Setelah menjalani serangkaian prosedur pemeriksaan, sampel dibagi ke dalam 3 kelompok, yaitu kelompok sehat 
endemik TB, kelompok kontak TB, dan kelompok pasien TB dengan melihat persentase IL2 dan IL10 CD8. Penelitian ini telah disetujui oleh Komisi Etik Fakultas Kedokteran Universitas Brawijaya Malang dan Komisi Etik Penelitian Kesehatan Badan Litbangkes Kementerian Kesehatan RI (LB.02.01/5.2/KE.396/2015).

Sampel diambil darahnya sebanyak $12 \mathrm{~mL}$ yang kemudian disimpan dalam vacutainer heparin. Darah yang telah diambil kemudian dicampur secara perlahan dengan PBS sebesar 1:1. Setelah itu sampel darah dipindahkan ke dalam botol sentrifus yang berisi ficoll-hipaque dengan perbandingan 1:1. Sampel darah kemudian disentrifus dengan kecepatan 1000rpm selama 30 menit dalam suhu ruang. Setelah disentrifus, maka sampel akan terpisah menjadi 5 lapisan. Cincin PBMC yang terbentuk diambil perlahan dengan mikropipet kemudian dipindahkan ke botol sentrifus untuk dicuci dengan $10 \mathrm{~mL}$ larutan PBS dan disentrifus kembali dengan kecepatan 1200rpm selama 10 menit dalam suhu ruang. Setelah pelet terbentuk, maka supernatan dibuang untuk kemudian sel dicuci 2 kali. Sebanyak $10^{6}$ PBMC (setelah dihitung) dalam 100ul Iscove's Modified Dulbecco's Medium (Sigma-Aldrich) dibagi dalam 3 perlakuan. Sebagai kontrol negatif sel dikultur tanpa protein rekombinan Mtb dan/atau PPD, sebagai kontrol positif sel dikultur dengan PPD $2 \mu \mathrm{g} / \mathrm{ml}$ (Statens Serum Institut Denmark), kelompok ketiga dikultur dengan protein rekombinan fusi ESAT6-CFP10 Mtb $2 \mu \mathrm{g} / \mathrm{ml}$ (BioFarma). Sel kemudian dikultur menggunakan RPMI 1640, natrium bicarbonat 0,2\%, buffer Hepes 0,28\%, Penstrep 0,25\%, PBS10X selama 48 jam dalam inkubator $37^{\circ} \mathrm{C}, 5 \% \mathrm{CO}_{2}$, in triplicate.

Supernatan diambil dan dimasukkan dalam $96 \mathrm{~V}$ bottom plate dan disimpan dalam $-20^{\circ} \mathrm{C}$. 4 jam sebelum dipanen diberikan Brefeldin A (Golgiplug) 10 $\mathrm{g} / \mathrm{ml}$. Kultur dipanen pada jam ke 48. Antibodi CD8 yang telah diencerkan dengan cell staining buffer dengan perbandingan 1:100, diambil sebanyak $50 \mu \mathrm{l}$ dan di campurkan dengan pelet PBMC hingga homogen. Cell staining buffer merupakan larutan yang dibuat dari 2\% Fetal Bovine Serum (FBS) dalam PBS. Pelet PBMC kemudian dibagi ke dalam beberapa eppendorf sesuai dengan banyaknya perlakuan. Pelet yang telah diberi antibodi CD8 diinkubasi selama 20 menit dalam gelap di suhu ruang. Pelet yang telah diinkubasi dengan antibodi CD8 kemudian dicuci dengan $500 \mu \mathrm{l}$ cell staining buffer, disentrifus pada suhu $4^{\circ} \mathrm{C}$ dengan kecepatan 2500rpm selama 3 menit. Selanjutnya supernatan dibuang, dan pelet yang terbentuk dicuci dengan 500 $\mu \mathrm{l}$ larutan fix buffer, dihomogenkan dan disentrifus pada suhu $4^{\circ} \mathrm{C}$ dengan kecepatan 2500rpm selama 3 menit. Supernatan yang terbentuk dibuang, kemudian pelet difiksasi dengan 500 $\mu$ l fix buffer lalu diinkubasi selama 20 menit dalam gelap di suhu ruang. Setelah inkubasi selesai, larutan disentrifus pada suhu $4^{\circ} \mathrm{C}$ dengan kecepatan 2500rpm selama 3 menit. Supernatan yang terbentuk dibuang, pelet dicuci dengan larutan permeable wash buffer, kemudian disentrifus pada suhu $4^{\circ} \mathrm{C}$ dengan kecepatan $2500 \mathrm{rpm}$ selama 3 menit. Supernatan yang terbentuk dibuang, kemudian masingmasing pelet distaining dengan $50 \mu \mathrm{l}$ antibodi IL2 dan IL10 yang telah diencerkan, kemudian diinkubasi dalam gelap di suhu ruang selama 20 menit. Setelah diinkubasi dicuci dengan menambahkan $500 \mu$ l larutan perm wash buffer dan disentrifus pada suhu $4^{\circ} \mathrm{C}$ dengan kecepatan $2500 \mathrm{rpm}$ selama 3 menit. Supernatan yang terbentuk dibuang dan ditambahkan $350 \mu \mathrm{l}$ sel staining buffer, kemudian dipindahkan ke kuvet baca dan siap untuk dibaca dengan

\section{flow cytometry.}

Dalam penelitian ini dilakukan analisis respon imun berupa pengukuran persentase IL2 dan IL10 yang dipresentasikan sel T CD8 dari PBMC terhadap paparan protein rekombinan fusi ESAT6-CFP10 pada 3 kelompok subjek penelitian yaitu kelompok sehat, kontak TB dan pasien TB. Pengukuran dilakukan dengan flow cytometry menghasilkan data berupa diagram histogram. Total sampel yang diukur adalah 72 sampel kultur PBMC yang terbagi dalam 9 subgrup dipisahkan berdasarkan kelompok subjek (sehat, kontak TB, pasien TB) dan perlakuan (tanpa antigen, PPD, protein fusi rekombinan ESAT6-CFP10). Setelah proses pewarnaan dengan marker maka selanjutnya dilakukan proses penghitungan sel dengan menggunakan flowcytometry.

A
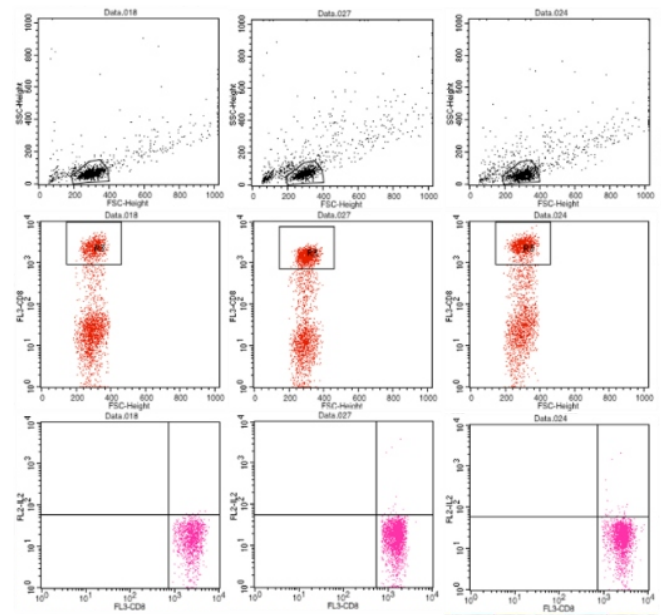

A. Sehat

B. Kontak TB

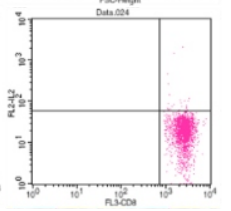

C. Pasien TB

B
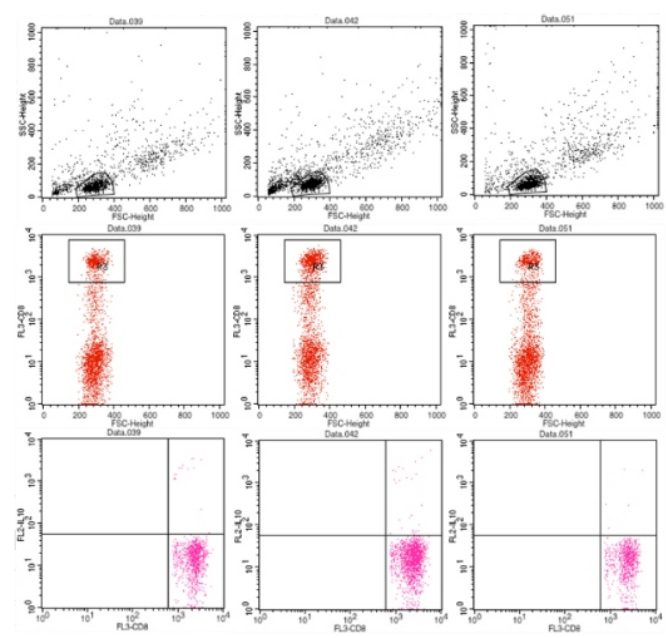

A. Sehat

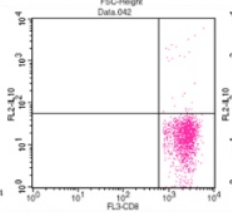

B. Kontak TB

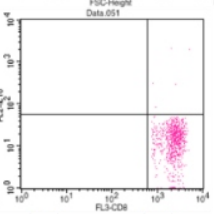

C. Pasien TB

Gambar 1. Hasil flow cytometry pada pemberian protein fusi rekombinan ESAT6-CFP10

(A. Sehat; B. Kontak TB; C. Pasien TB)

Keterangan:

A. Hasil flow cytometry ekspresi IL2 sel T CD8

B. Hasil flow cytometry ekspresi IL10 sel T CD8

Dari diagram dot plot dapat dilihat bahwa PBMC pada mulanya dipisahkan dengan pengelompokan (gating) 
berdasarkan karakteristik sel T CD8. Sel T CD8 yang telah ditambahkan marker ekstraseluler akan memberikan karakteristik tertentu yang tertangkap oleh flowcytometry. Selanjutnya dilakukan pengelompokan sel T CD8 berdasarkan karakteristik yang dimiliki sel T CD8. Setelah dikelompokkan, selanjutnya dilakukan pengelompokan berdasarkan karakteristik yang dimiliki oleh sel T CD8 pemroduksi IL2 dan IL10. IL2 dan IL10 yang dipresentasikan oleh sel T CD8 akan menyebabkan sel tersebut nantinya tertangkap di dot plot berada di kuadran kanan atas. Persentase sel pada masing-masing kuadran dapat dilihat di tabel yang tersedia di bawah dot plot. Software yang digunakan untuk menganalisis data adalah SPSS (Statistical Package for Social Science) for windows versi 24 . Untuk membandingkan produksi IL2 dan IL10 sel CD8 antar kelompok kelompok sehat endemik TB, kelompok kontak TB, dan kelompok pasien TB digunakan one way ANOVA, dengan tingkat kebermaknaan $\mathrm{p}<0,05$.

\section{HASIL}

Responden penelitian ini terdiiri dari 24 subjek dengan masing masing kelompok studi terdiri dari 8 orang subjek sehat, subjek kontak TB, dan subjek pasien TB. Subjek penelitian telah memenuhi kriteria inklusi dan eklusi subjek penelitian dan telah menandatangani persetujuan (informed consent). Tabel 1 menunjukkan karakteristik subjek penelitian subjek berada pada rentang usia 21-50 tahun, dengan subjek pasien TB paling banyak terdapat pada rentang usia 40-50 tahun. Pada kelompok pasien jumlah laki-laki (6 orang) lebih banyak daripada perempuan ( 2 orang) yang berbanding terbalik dengan kelompok sehat. Pada kelompok kontak didapatkan jumlah laki-laki sama dengan perempuan. Dari 6 orang laki-laki pasien TB diketahui bahwa semuanya merupakan perokok aktif, sedangkan 2 orang perempuan pasien TB bukan merupakan perokok aktif. Pada kelompok kontak dan sehat didapatkan bahwa tidak ada subjek yang perokok aktif. Berdasarkan Indek Masa Tubuh (IMT) paling banyak pada subjek pasien TB memiliki IMT <18,5 (5 orang), 2 orang memiliki IMT antara 18,5-23, tetapi tidak ada pasien yang memiliki IMT >23. Pada kelompok kontak TB dan kelompok sehat hampir semua responden memiliki IMT >18,5.

Hampir seluruh responden memiliki scar BCG kecuali pada 2 subjek penelitian pada kelompok pasien TB tidak memiliki skar BCG. Pemeriksaan mantoux didapatkan pada seluruh subjek kelompok pasien dan kontak. Gejala klinis TB hanya didapatkan pada kelompok pasien TB yang merupakan gejala respiratorik dan sistemik yang sering terjadi pada penderita penyakit TB dan merupakan salah satu kriteria diagnosa. Batuk merupakan gejala yang paling banyak menyertai penyakit TB pada studi ini didapatkan pada seluruh kelompok subjek TB. Keluhan demam pada 7 orang subjek TB, keringat malam 6 orang dan penurunan berat badan 5 orang, merupakan keluhan terbanyak setelah batuk. Beberapa pasien juga mengeluhkan batuk darah 2 orang, sesak dan nyeri dada masing masing 1 orang. Pada gambaran foto toraks paling banyak (6 orang) didapatkan gambaran paru far advanced lesion dari subjek penderita TB dan tidak didapatkan minimal lesion pada subjek penderita TB. Pada kesuluruhan subjek kelompok pasien didapatkan hasil pemeriksaan smear sputum BTA+ sesuai dengan syarat dalam kelompok Pasien TB. BTA +1 dan +2 didapatkan pada masing masing 3 subjek, BTA +3 didapatkan pada 2 orang pasien.

Tabel 1. Karakteristik subjek penelitian

\begin{tabular}{|c|c|c|c|c|}
\hline \multicolumn{2}{|c|}{ Karakteristik } & \multirow{2}{*}{$\begin{array}{c}\begin{array}{c}\text { Sehat } \\
(n=8)\end{array} \\
1\end{array}$} & \multirow{2}{*}{$\begin{array}{c}\begin{array}{c}\text { Kontak } \\
(\mathbf{n}=8)\end{array} \\
0\end{array}$} & \multirow{2}{*}{$\begin{array}{c}\begin{array}{c}\text { Pasien } \\
(n=8)\end{array} \\
0\end{array}$} \\
\hline \multirow{4}{*}{ Usia } & $<20$ & & & \\
\hline & $21-30$ & 2 & 3 & 4 \\
\hline & $31-40$ & 1 & 4 & 4 \\
\hline & $41-50$ & 4 & 1 & 0 \\
\hline \multirow{2}{*}{ Jenis Kelamin } & Laki-laki & 6 & 4 & 2 \\
\hline & Perempuan & 2 & 4 & 6 \\
\hline \multirow{2}{*}{$\begin{array}{l}\text { Riwayat } \\
\text { merokok }\end{array}$} & Merokok & 6 & 0 & 0 \\
\hline & Tidak & 2 & 8 & 8 \\
\hline \multirow{3}{*}{$\begin{array}{l}\text { Indeks Masa } \\
\text { Tubuh }\end{array}$} & $<18,5$ & 5 & 1 & 0 \\
\hline & $18,5-23$ & 2 & 2 & 6 \\
\hline & $>23$ & 1 & 5 & 2 \\
\hline \multicolumn{2}{|l|}{ BCG Scar (+) } & 6 & 8 & 8 \\
\hline \multicolumn{2}{|l|}{ Mantoux Test } & 8 & 8 & 0 \\
\hline \multirow{7}{*}{ Gejala Klinis } & Batuk & 8 & - & - \\
\hline & Batuk darah & 2 & - & - \\
\hline & Sesak & 1 & - & - \\
\hline & Nyeri Dada & 1 & - & - \\
\hline & Demam & 7 & - & - \\
\hline & Keringat Malam & 6 & - & - \\
\hline & Penurunan BB & 5 & - & - \\
\hline \multirow{3}{*}{ Foto Toraks } & Minimal & 0 & \multirow{6}{*}{$\begin{array}{c}\text { Negatif } \\
(-)\end{array}$} & \multirow{3}{*}{$\mathrm{N}$} \\
\hline & Moderate & 2 & & \\
\hline & Far advanced & 6 & & \\
\hline \multirow{3}{*}{ BTA } & +1 & 3 & & \multirow{3}{*}{$\begin{array}{c}\text { Negatif } \\
(-)\end{array}$} \\
\hline & \multirow{2}{*}{$\begin{array}{l}+2 \\
+3\end{array}$} & 3 & & \\
\hline & & 2 & & \\
\hline
\end{tabular}

Hasil pengukuran IL2 sel T CD8 dari PBMC (Tabel 2) menunjukkan bahwa kelompok protein rekombinan fusi ESAT6-CFP10 memiliki persentase IL2 yang lebih tinggi dibandingkan kelompok tanpa antigen baik pada kelompok sehat $(0,576 \pm 0,190)$, kontak $(1,022 \pm 0,506)$, atau pasien $(1,217 \pm 0,498)$. Namun demikian analisis one way ANOVA memperlihatkan bahwa perbedaan persentase IL2 pada kelompok sehat $(p=0,309)$, kontak TB $(p=0,318)$, atau pasien TB $(p=0,424)$ tidak signifikan $(p>0,05)$. Terdapat perbedaan persentase IL2 yang signifikan antar kelompok sehat, kontak, dan pasien TB yang dipaparkan dengan protein rekombinan fusi ESAT6-CFP10 $(p=0,019)$ dan pada kelompok tanpa antigen $(p=0,026)$. Pada kelompok sehat, kontak, dan pasien TB yang dipaparkan dengan PPD tidak terdapat perbedaan yang signifikan dari persentase IL2 ( $p=0,396)$.

Tabel 2. Persentase IL2 yang dipresentasikan sel T CD8 pada PBMC yang dipaparkan protein ESAT6-CFP10, PPD, dan tanpa antigen

\begin{tabular}{|c|c|c|c|c|}
\hline \multirow{3}{*}{ Kelompok } & \multicolumn{3}{|c|}{ IL2 } & \multirow{3}{*}{$p$-value } \\
\hline & Sehat & Kontak & Pasien & \\
\hline & Rata2 \pm sd (\%) & Rata2 \pm sd (\%) & Rata2 \pm sd (\%) & \\
\hline Tanpa Ag & $0,557 \pm 0,211$ & $0,695 \pm 0,296$ & $0,946 \pm 0,285$ & $0,026^{a}$ \\
\hline PPD & $0,738 \pm 0,333$ & $1,007 \pm 0,577$ & $1,025 \pm 0,439$ & $0,396^{b}$ \\
\hline ESAT6-CFP10 & $0,576 \pm 0,190$ & $1,022 \pm 0,505$ & $1,217 \pm 0,498$ & $0,019^{a}$ \\
\hline$p$-value & $0,309^{b}$ & $0,318^{b}$ & $0,424^{b}$ & \\
\hline
\end{tabular}

Keterangan: $\left.{ }^{a}\right)$ Terdapat perbedaan signifikan $\left.(p<0,05),{ }^{b}\right)$ Tidak terdapat perbedaan signifikan $(p>0,05)$ 
Hasil pengukuran IL10 sel T CD8 dari PBMC (Tabel 3) memperlihatkan bahwa kelompok protein rekombinan fusi ESAT6-CFP10 memiliki persentase IL10 yang lebih tinggi dibandingkan kelompok tanpa antigen baik pada kelompok sehat $(0,617 \pm 0,306)$, kontak TB $(1,047 \pm 0,689)$, atau pasien TB $(0,857 \pm 0,444)$. Persentase IL10 pada berbagai kelompok dapat dilihat pada Tabel 3. Namun demikian analisis one way ANOVA memperlihatkan perbedaan persentase IL10 pada kelompok sehat $(p=0,908)$, kontak TB $(p=0,352)$, atau pasien TB $(p=0,776)$ tidak signifikan $(p>0,05)$. Penambahan protein fusi ESAT6CFP10 pada PBMC antar kelompok juga menunjukkan persentase IL10 yang tidak signifikan $(p=0,257)$, diikuti oleh PPD $(p=0,351)$, dan perlakuan tanpa antigen $(p=0,617)$.

Tabel 3. Persentase IL10 yang dipresentasikan sel T CD8 pada PBMC yang dipaparkan protein ESAT6-CFP10, PPD, dan tanpa antigen

\begin{tabular}{|c|c|c|c|c|}
\hline \multirow{3}{*}{ Kelompok } & \multicolumn{3}{|c|}{ IL10 } & \multirow{3}{*}{$p$-value } \\
\hline & Sehat & Kontak & Pasien & \\
\hline & Rata2 \pm sd (\%) & Rata2 \pm sd (\%) & Rata2 \pm sd (\%) & \\
\hline Tanpa Ag & $0,613 \pm 0,228$ & $0,721 \pm 0,233$ & $0,755 \pm 0,397$ & $0,617^{b}$ \\
\hline PPD & $0,665 \pm 0,237$ & $0,817 \pm 0,289$ & $0,901 \pm 0,414$ & $0,351^{b}$ \\
\hline ESAT6-CFP10 & $0,617 \pm 0,306$ & $1,047 \pm 0,689$ & $0,857 \pm 0,444$ & $0,257^{b}$ \\
\hline$p$-value & $0,908^{b}$ & 0,352 & $0,776^{b}$ & \\
\hline
\end{tabular}

\section{DISKUSI}

Penelitian ini mengidentifikasi dari 8 orang subjek dengan TB diantaranya 4 orang berusia diatas 40 tahun (rentang usia 41-50 tahun). Zhang berpendapat bahwa usia memiliki peranan penting dalam menentukan klinis dari pasien TB karena semakin bertambahnya usia maka ketahanan tubuh terhadap penyakit semakin menurun (12). Pada studi ini jenis kelamin laki laki lebih mendominasi daripada perempuan (75\%), sesuai dengan data Profil Kesehatan Indonesia tahun 2016 yang menunjukkan penderita tuberkulosis laki laki mencapai 95.382 jiwa (61\%) dan wanita 61.341 jiwa (39\%) (2). Laki laki lebih rentan menderita TB dibandingkan dengan wanita karena salah satu faktor risiko adalah kebiasan merokok pada laki laki $(13,14)$. Dari seluruh penderita TB, 6 orang memiliki Indek Masa Tubuh (IMT) <18 (rendah), sedangkan pada responden sehat dan kontak tidak ada yang memiliki IMT <18. Semakin parah penyakit TB akan menurunkan nafsu makan dan semakin memperparah kondisi malnutrisi (15). Skar BCG pada pasien TB menunjukkan pasien sudah pernah diimunisasi BCG. Pada penelitian ini didapatkan bahwa vaksinasi tidak menjamin seseorang kebal terhadap infeksi TB (16-18). Pada infeksi baru, responden yang datang berobat ke Rumah Sakit Umum Dr. Saiful Anwar (RSSA) karena keluhan batuk yang tidak segera membaik dengan pengobatan biasa mencapai $100 \%$. Responden TB yang datang juga memiliki keluhan klinis antara lain batuk darah, sesak, nyeri dada, demam, keringat malam, dan penurunan berat badan. Keluhan batuk merupakan respon tubuh dalam usaha melindungi diri dengan membersihkan mukocilliari. Selama peradangan kronis, pembuluh darah di sekitar tempat yang terinfeksi membesar dan sangat rentan terjadi kerusakan. Kebocoran pembuluh darah menyebabkan pasien batuk tidak hanya mengandung sekret purulen tetapi juga darah (19).

Pasien yang demam dengan keringat malam mendominasi, demam dan keringat malam yang terjadi merupakan respon pertahanan tubuh. Th1 akan menghasilkan Tumor Necrosis Factor Alpha (TNF $\alpha$ ). Menariknya, TNF $\alpha$ ini diproduksi secara besar-besaran di malam hari dan beberapa studi ekstensif telah dilakukan dan diyakini bahwa peningkatan tajam dalam tingkat serum TNF $\alpha$ menyebabkan rangsangan pada hipotalamus yang melibatkan prostaglandin yang menyebabkan peningkatan suhu badan, keringat malam pada pasien TB untuk melepaskan panas tubuh (20). Untuk pemilihan responden kedalam kelompok pasien TB, kontak TB dan sehat pada daerah endemik TB seperti Indonesia, skrining dilakukan melalui pemeriksaan bakteriologis. Foto toraks adalah alat skrining paling sensitif untuk mengidentifikasi subjek dengan probabilitas tinggi untuk terdiagnosis TB. Gabungan pemeriksaan foto toraks, kultur atau uji bakteriologis akan menghasilkan estimasi penyakit TB yang paling akurat. Untuk membedakan TB laten (kontak TB) dengan sehat endemik dilakukan Tuberculin Skin Test (TST) atau tes Mantoux. Hasil tes Mantoux $>10 \mathrm{~mm}$ (positif) pada subjek daerah endemik (tanpa adanya keadaan imunocompromised) akan dimasukkan kelompok kontak. Pada responden penelitian ini kelompok pasien TB seluruhnya memiliki hasil bakteriologi dahak positif baik dengan hapusan BTA mikroskopis maupun dengan pemeriksaan molekuler (GeneXpert) ditunjang dengan pemeriksaan foto toraks didapatkan kelainan pada paru yang khas pada penderita TB. Tes mantoux positif dengan diameter indurasi $>10 \mathrm{~mm}$ tanpa gangguan imun pada daerah endemik (subjek pasien TB dan kontak TB) menunjukkan riwayat paparan terhadap kuman Mtb (1).

Pada penelitian ini dilakukan penilaian terhadap persentase IL2 dan IL10 yang dipresentasikan sel T CD8 pada kultur PBMC berbagai kelompok yang dipaparkan protein rekombinan fusi ESAT6-CFP10 yang sangat penting dalam proses imunitas perlindungan terhadap TB. Studi yang dilakukan pada tahun 2007 oleh Meher et al., menunjukkan bahwa ESAT6 dan CFP10 dapat merangsang respon sel T sitotoksik pada model hewan percobaan, dimana sel T sitotoksik diketahui memiliki peran besar dalam memberikan pertahanan terhadap TB (21). Penelitian ini membagi sampel kedalam 3 kelompok dengan harapan mengetahui kemampuan protein rekombinan fusi ESAT6-CFP10 selain sebagai vaksin profilaksis juga sebagai vaksin terapeutik. Vaksin terapeutik memiliki fungsi untuk melawan infeksi yang sedang berlangsung, sedangkan vaksin profilaksis berfungsi mencegah munculnya infeksi baru. Vaksin terapeutik bekerja dengan merangsang respon imun terhadap antigen tertentu untuk meningkatkan produksi sitokin dan antibodi yang berperan dalam proses melawan infeksi. Protein rekombinan fusi ESAT6-CFP10 selain sebagai kandidat vaksin (profilaksis atau terapeutik) tampaknya lebih tepat untuk meningkatkan imunogenitas vaksin BCG atau sebagai booster pada subjek yang telah divaksin BCG sebelumnya (22). Interaksi antara Mtb dan sel inang sendiri sangat kompleks dan belum sepenuhnya dapat dijelaskan. Belum diketahui pasti mekanisme yang tepat bagaimana rekombinan fusi ESAT6 dan CFP10 meningkatkan ekspresi sitokin dan sel $T$ polifungsional yang dominan pada percobaan hewan coba (23). Diharapkan protein rekombinan fusi ESAT6-CFP10 yang 
baru dapat mempertahankan jumlah sel memori dalam waktu yang lama dan kualitas yang baik dalam arti mampu mengekspresikan sel T multifungsional pada paparan Mtb $(24,25)$.

Pada imunitas perlindungan tubuh terhadap infeksi Mtb, IL2 berguna untuk mempercepat proliferasi sel T CD8 dan diferensiasi menjadi sel T sitotoksik (6). Selain itu IL2 juga berperan sebagai faktor pertumbuhan dan diferensiasi dari sel NK, sel limfosit B, dan sel limphokine-activated killer (LAK) (10). Keberadaan IL2 diketahui ikut meningkatkan kadar IFN- $\gamma$ yang diproduksi oleh sel T CD8 sehingga meningkatkan kemampuan tubuh dalam mengeradikasi kuman Mtb (11). Disisi lain IL10 merupakan sitokin anti-inflamasi dengan banyak peran seperti supresi Treg, menurunkan TNF- $\alpha$ yang diproduksi makrofag, mengurangi sitokin yang diproduksi oleh Th1, dan menekan proliferasi sel T (12). Selain itu IL10 juga berperan dalam maturasi sel T CD8 sitotoksik serta diferensiasi sel T memori (26). Pada studi ini persentase IL2 dan IL10 pada kelompok sehat, kontak TB, dan sakit TB yang mendapatkan paparan protein rekombinan fusi ESAT6-CFP10, PPD, dan tanpa antigen tidak menunjukkan perbedaan yang bermakna secara statistik. Hal ini dapat disebabkan karena IL2 dan IL10 bukanlah respon imun spesifik yang ditimbulkan setelah paparan protein rekombinan fusi ESAT6-CFP10 seperti misalnya sel memori ataupun antibodi spesifik. Selain itu perbedaan yang tidak signifikan bisa terjadi diduga karena protein rekombinan fusi ESAT6-CFP10 dipresentasikan oleh APC melalui MHC kelas 2 sehingga sitokin proinflamasi seperti IL2 yang dipresentasikan sel T CD8 tidak mengalami peningkatan yang signifikan. Kenaikan IL2 terjadi tergantung kuat tidaknya stimulasi yang diberikan oleh APC kepada sel limfosit naif. Pada infeksi TB, Mtb sebagai patogen intrasel dipresentasikan melalui MHC kelas 1 oleh APC yang kemudian mengaktivasi sel T CD8. Hal ini kemudian akan meningkatkan sitokin-sitokin yang berperan dalam maturasi dan proliferasi dari sel T CD8 seperti IL2 (21).

Temuan yang menarik dari studi ini adalah tampak bahwa persentase IL2 sel T CD8 yang dipapar dengan ESAT6CFP10 baik pada subjek sehat, kontak TB, dan pasien TB

\section{DAFTAR PUSTAKA}

1. World Health Organization. Global Tuberculosis Report 2016 . (On I ine) 2016 . ht t p://apps.who.int/medicinedocs /en/d/Js23098en/

2. Direktorat Jendral Pengendalian Penyakit dan Penyehatan Lingkungan. Pedoman Nasional Pengendalian Tuberkulosis. Jakarta: Kementerian Kesehatan Nasional; 2014; hal. 1-210.

3. Das K, Thomas T, Garnica O, and Dhandayuthapani S. Recombinant Bacillus subtilis spores for the delivery of Mycobacterium tuberculosis Ag85B-CFP10 secretory antigens. Tuberculosis (Edinburgh, Scotland). 2016; 101: 18-27.

4. Handzel ZT. The Immune Response to Mycobacterium tuberculosis Infection in Humans. Diagnosis and Management 2013; 15(2): 19-30.

5. Brandt L, Elhay M, Rosenkrands I, Lindblad EB, and Andersen P. ESAT-6 Subunit Vaccination against Mycobacterium tuberculosis. Infection and lebih tinggi dibandingkan dengan tanpa paparan antigen. Perbedaan ini menunjukkan bahwa rekombinan fusi ESAT6 dan CFP10 mampu menginduksi terbentuknya sitokin IL2 meski bukan sebagai respon imun spesifik. Selain itu persentase IL2 antara kelompok sehat, kontak TB, dan pasien TB yang dipaparkan dengan protein fusi ESAT6CFP10 menunjukkan adanya perbedaan yang signifikan seperti pada perbedaan IL2 antar kelompok tanpa paparan antigen. Hal ini menunjukkan adanya perbedaan persentase IL2 yang bermakna pada kelompok sehat, kelompok kontak TB, dan kelompok pasien TB yang dipaparkan dengan protein fusi ESAT6-CFP10. Perbedaan persentase IL2 yang signifikan antara kelompok sehat, kontak TB, dan pasien TB yang tidak dipaparkan antigen menunjukkan bahwa subjek dalam masing-masing kelompok memang betul sesuai dengan pembagian kelompok. Pada kelompok sehat, adalah betul subjek sehat yang didalam tubuhnya hanya ada sel memori yang terbentuk setelah vaksinasi BCG dan bukan pasien TB laten ataupun pasien TB yang telah mengalami eradikasi Mtb sempurna. Sebaliknya pada kelompok kontak sudah terdapat sel memori yang terbentuk paska infeksi TB seperti pasien TB akan tetapi tanpa adanya manifestasi gejala klinis. Persentase IL10 yang dipresentasikan sel T CD8 baik pada subjek sehat maupun kontak TB juga lebih tinggi dibandingkan dengan tanpa pemberian antigen. Perbedaan ini menunjukkan bahwa rekombinan fusi ESAT6-CFP10 mampu mengindukksi terbentuknya sitokin IL10 meskipun secara statistik tidak bermakna. Meskipun tidak bermakna hal ini menunjukkan persentase IL10 lebih tinggi setelah dipaparkan protein fusi rekombinan ESAT6CFP10 dibandingkan dengan persentase IL10 setelah paparan PPD.

Penelitian ini menunjukkan bahwa meskipun peningkatan yang didapat tidak bermakna secara statistik, akan tetapi protein rekombinan fusi ESAT6-CFP10 menunjukkan kemampuannya dalam meningkatkan persentase IL2 dan IL10 tidak jauh berbeda dengan PPD. Diharapkan akibat rangsangan awal oleh protein rekombinan fusi ESAT6CFP10, dapat tercipta kekebalan yang mirip dengan kondisi paska infeksi TB.

Immunity. 2000; 68(2): 791-795.

6. Kumar MM and Raja A. Cytotoxicity Responses to Selected ESAT-6 and CFP-10 Peptides in Tuberculosis. Cellular Immunology. 2010; 265(2): 146-155.

7. Dong $\mathrm{H}$, Jing $\mathrm{W}$, Runpeng $\mathrm{Z}$, et al. ESAT6 Inhibits Autophagy Flux and Promotes BCG Proliferation through MTOR. Biochemical and Biophysical Research Communications. 2016; 477(2): 195-201.

8. Guo S, Xue R, Li Y, et al. The CFP10/ESAT6 Complex of Mycobacterium tuberculosis May Function as a Regulator of Macrophage Cell Death at Different Stages of Tuberculosis Infection. Medical Hypotheses. 2012; 78(3): 389-392.

9. Abbas AK, Lichtman $\mathrm{AH}$, and Pillai S. Basic Immunology: Functions and Disorders of the Immune System. Philadelphia: Elsivier Sanders; 2016; pp. 232233, 243-244.

10. Prayitno A, Astirin OP, and Putra ST. Immune Response Indicated by Expressing of IL-2 and IL-10 in Cervical Cancer. Journal of Cancer Therapy. 2014; 
5(5): 420-426.

11. Sa Q, Woodward J, and Suzuki Y. IL-2 Produced By CD8+ Immune T Cells Can Augment Their IFN- $\Gamma$ Production Independently from Their Proliferation in the Secondary Response to an Intracellular Pathogen. The Journal of Immunology. 2013; 190(5): 2199-2207.

12. Zhang N and Bevan MJ. CD8+ T Cells: Foot Soldiers of the Immune System. 2011; 35(2): 161-168.

13. Nhamoyebonde $S$ and Leslie A. Biological Differences between the Sexes and Susceptibility to Tuberculosis. The Journal of infectious diseases. 2014; 209(3): 100106.

14. Jiménez-Corona ME, García-García L, DeRiemer K, et al. Gender Differentials of Pulmonary Tuberculosis Transmission and Reactivation in an Endemic Area. Thorax. 2006; 61(4): 348-353.

15. Chang KC and Yew WW. Management of Difficult Multidrug-Resistant Tuberculosis and Extensively Drug-Resistant Tuberculosis: Update 2012. Respirology. 2013; 18(1): 8-21.

16. Mangtani P, Abubakar I, Ariti C, et al. Protection by BCG Vaccine Against Tuberculosis: A Systematic Review of Randomized Controlled Trials. Clinical Infectious Diseases. 2014; 58(4): 470-480.

17. Husain AA, Daginawala HF, Singh L, and Kashyap RS. Current Perspective in Tuberculosis Vaccine Development for High TB Endemic Regions. Tuberculosis (Edinburgh, Scotland). 2016; 98: 149-158.

18. Tanner R, O'Shea MK, Fletcher HA, and McShane H. In Vitro Mycobacterial Growth Inhibition Assays: A Tool for the Assessment of Protective Immunity and Evaluation of Tuberculosis Vaccine Efficacy. Vaccine. 2016; 34(39): 4656-4665.

19. Turner RD and Bothamley GH. Cough and the
Transmission of Tuberculosis. The Journal of Infectious Diseases. 2015; 211(9): 1367-1372.

20. Buyukoglan H, Gulmez I, Kelestimur F, et al. Leptin Levels in Various Manifestations of Pulmonary Tuberculosis. Mediators of Inflammation. 2007; 5: 1-6.

21. Meher AK, Lella RK, Sharma C, and Arora A. Analysis of Complex Formation and Immune Response of CFP10 and ESAT-6 Mutants. Vaccine. 2007; 25(32): 60986106.

22. Nugrahani IT, Kusuma HMSC, Raras TMR, Arthamin $\mathrm{MZ}$, Astuti TW, dan Tanoerahardjo F. Ekspresi IFN- $\gamma$ dan IL-4 CD4+T Limfosit pada Tuberkulosis Kontak terhadap Antigen $38 \mathrm{Kda}$ Mycobacterium tuberculosis. Jurnal Kedokteran Brawijaya. 2015; 28(4): 302-308.

23. Kleinnijenhuis J, Oosting M, Joosten LAB, Netea MG, and Crevel RV. Innate Immune Recognition of Mycobacterium tuberculosis. Clinical and Developmental Immunology. 2011; 2011: 1-12.

24. Maue AC, Waters WR, Palmer MV, et al. An ESAT6:CFP10 DNA Vaccine Administered in Conjunction with Mycobacterium Bovis BCG Confers Protection to Cattle Challenged with Virulent M. Bovis. Vaccine. 2007; 25(24): 4735-4746.

25. Lindenstrom T, Agger EM, Korsholm KS, et al. Tuberculosis Subunit Vaccination Provides Long-Term Protective Immunity Characterized by Multifunctional CD4 Memory T Cells. The Journal of Immunology. 2009; 182(12): 8047-8055.

26. Yuan N, Zhang HF, Wei Q, Wang $P$, and Guo WY. Expression of CD4+CD25+Foxp3+Regulatory T Cells, Interleukin 10 and Transforming Growth Factor $B$ in Newly Diagnosed Type 2 Diabetic Patients. Experimental and Clinical Endocrinology \& Diabetes. 2018; 126(2): 96-101. 